\title{
Blinatumomab - nowy lek u chorych na nawrotową/ /oporną ostrą białaczkę limfoblastyczną
}

\author{
Blinatumomab - a novel drug in patients \\ with relapsed/refractory acute lymphoblastic leukemia
}

\author{
Joanna Sawczuk-Chabin ${ }^{1}$, Anna Ejduk ${ }^{1}$, Ewa Lech-Marańda ${ }^{1,2}$ \\ ${ }^{1}$ Klinika Hematologii, Instytut Hematologii i Transfuzjologii, Warszawa \\ ${ }^{2}$ Klinika Hematologii i Transfuzjologii, Centrum Medyczne Kształcenia Podyplomowego, Warszawa
}

\begin{abstract}
Streszczenie
Wyniki leczenia dorostych pacjentów z nawrotowa/oporna (R/R) ostra biataczka limfoblastycznq (ALL) sq niezadowalajace. Nie ma ustalonych standardów postepowania w leczeniu wznowy $A L L$, a terapia reindukujaca powinna stanowić jedynie ,leczenie pomostowe” do wykonania przeszczepienia allogenicznych krwiotwórczych komórek macierzystych. Przy zastosowaniu standardowej chemioterapii czas trwania odpowiedzi, jeśli uda sie ja uzyskać, jest zwykle krótki, a kolejne nawroty cechuje chemiooporność. Immunoterapia z zastosowaniem przeciwciat monoklonalnych stanowi nowe podejście do leczenia chorych na $R / R$ ALL, a jej celem jest wydtużenie przeżycia wolnego od nawrotu choroby i przeżycia catkowitego bez istotnego zwiększenia toksyczności leczenia. W pracy omówiono mechanizm dziatania $i$ skuteczność kliniczna blinatumomabu - nowego bispecyficznego przeciwciata monoklonalnego. W 2015 roku blinatumomab uzyskat rejestracje Europejskiej Agencji ds. Leków do leczenia chorych na $R / R$ B-komórkowa ALL bez obecności chromosomu Filadelfia.
\end{abstract}

Słowa kluczowe: blinatumomab, przeciwciała bispecyficzne, ostra białaczka limfoblastyczna

Hematologia 2016; 7, 4: 312-326

\section{Abstract}

The long term prognosis of adult patients with relapsed/refractory $(R / R)$ acute lymphoblastic leukemia $(A L L)$ is poor. There is no standard treatment for relapsed $A L L$ and reinduction therapy should only be a "bridge treatment" in allogeneic hematopoietic stem cell transplantation (allo-HSCT). In spite of obtaining an initial response to treatment, the duration of response using standard chemotherapy is usually short and the next relapses are chemoresistant. Immunotherapy with monoclonal antibodies as a targeted therapy represents a novel approach for treating patients with $R / R$ ALL. The objective of immunotherapy is to improve the relapse-free and overall survival without increasing the toxicity of treatment. In this review, the mechanism of action and clinical efficacy of the novel bispecific antibody blinatumomab is discussed. The European Medicines Agency approved blinatumomab in 2015 for treating adult patients with Philadelphia chromosome negative $R / R B$ - $A L L$.

Key words: blinatumomab, bispecific antibodies, acute lymphoblastic leukemia

Hematologia 2016; 7, 4: 312-326

Adres do korespondencji: Ewa Lech-Marańda, Klinika Hematologii, Instytut Hematologii i Transfuzjologii, ul. Indiry Gandhi 14, 02-776 Warszawa, tel. 22349 63 34, faks 22349 63 35, e-mail: emaranda@ihit.waw.pl 


\section{Wprowadzenie}

Leczenie chorych na ostrą białaczkę limfoblastyczną (ALL, acute lymphoblastic leukemia) obejmuje trzy etapy, tj. indukcję remisji, konsolidację oraz leczenie podtrzymujące, i różni się pod względem postaci ALL $z$ obecnością lub brakiem chromosomu Filadelfia (Ph, Philadelphia). Według zaleceń EBMT (European Society for Blood and Marrow Transplantation) wskazaniami do przeprowadzenia procedury allogenicznego przeszczepienia krwiotwórczych komórek macierzystych (allo-HSCT, allogeneic hematopoietic stem cell transplantation) od dawcy spokrewnionego lub niespokrewnionego jest ALL $z$ grupy wysokiego ryzyka w pierwszej całkowitej remisji (CR1) oraz nawrót choroby. U chorych $z$ grupy standardowego ryzyka allo-HSCT od dawcy spokrewnionego w CR1 pozostaje możliwą opcją kliniczną.

Mimo ponad 80-procentowego odsetka CR uzyskiwanych po leczeniu indukującym u dorosłych chorych na ALL Ph-ujemną (Ph-) do nawrotu choroby dochodzi u 30-60\% pacjentów, niezależnie od intensywności stosowanego leczenia konsolidującego i podtrzymującego remisję. Rokowanie $\mathrm{u}$ takich chorych jest niepomyślne. W badaniach przeprowadzonych przez Medical Research Council UKALL 12/ECOG2993 i grupę PETHEMA (Programa Para El Estudio Y Tratamiento De Las Hemopatİas Malignas) wykazano, że u pacjentów $z$ nawrotem po leczeniu pierwszej linii mediana przeżycia całkowitego (OS, overall survival) po nawrocie wynosi odpowiednio 6 miesięcy i 4,5 miesiąca, a 5-letnie OS po nawrocie osiagga $7 \%$ i $10 \%$ chorych $[1,2]$. Dodatkowo grupą $z$ bardzo złym rokowaniem są chorzy, u których stwierdza się pierwotną oporność na stosowaną terapię.

Nie ma ustalonych standardów postępowania w leczeniu wznowy ALL, a terapia reindukująca powinna być tak zwanym leczeniem pomostowym służącym uzyskaniu 2. lub kolejnej CR, a następnie jak najszybszemu wykonaniu allo-HSCT, które jest jedyną, jak dotąd, metodą dającą szansę na wyleczenie. Procedura allo-HSCT powinna stanowić cel terapii u chorych bez przeciwwskazań do jej wykonania. Wybór terapii reindukującej zależy między innymi od takich czynników, jak wiek pacjenta, obecność chorób współistniejących, czas trwania CR1 i rodzaj wcześniejszego leczenia, a także immunofenotyp komórek białaczkowych i obecność nacieków pozaszpikowych. Status choroby, w tym obecność minimalnej choroby resztkowej (MRD, minimal residual disease) w momencie wykonywania allo-HSCT, ściśle koreluje $z$ odległymi wynikami transplantacji. Idealnym, tj. cechującym się niskim ryzkiem nawrotu choroby, kandydatem do procedury allo-HSCT jest pacjent, u którego stwierdza się CR bez obecności MRD $[1,3]$. W analizie retrospektywnej u 547 chorych $z$ pierwszą wznową ALL zaobserwowano, że roczne OS osiągnęło $38 \%$ pacjentów, u których wykonano allo-HSCT w CR2, w porównaniu $z$ grupą chorych bez allo-HSCT, u których śmiertelność po roku wynosiła $100 \%$ [4]. Ocenia się, że 20-30\% chorych, u których rozpoznano wznowę choroby, uzyska CR2, a czynnikami zwiększającymi szansę na jej uzyskanie są młodszy wiek chorego i czas trwania CR1 powyżej 2 lat [2, 5]. Wykonanie tak zwanej ratunkowej allo-HSCT, tj. bez uzyskania $\mathrm{CR}$, tylko u niewielkiego odsetka chorych może doprowadzić do remisji choroby, a ryzyko kolejnego nawrotu zawsze pozostaje duże, dlatego decyzje o zastosowaniu takiej procedury należy podejmować indywidualnie $[1,3]$.

\section{Leczenie chorych na nawrotowa/oporną $\mathrm{ALL} \mathrm{Ph}(-)$}

Większość badaczy w przypadku nawrotu ALL stwierdzonego ponad rok od uzyskania CR w leczeniu drugiej linii stosuje ten sam schemat terapii, który doprowadził do uzyskania CR1. W praktyce oznacza to zastosowanie schematów opartych na antracyklinach, winkrystynie, asparaginazie i steroidach lub schematu HyperCVAD (cyklofosfamid, winkrystyna, doksorubicyna, deksametazon) podawanego naprzemiennie ze schematem MA (duże dawki metotreksatu i cytarabiny). Ten ostatni ze względu na fakt, że duże dawki metotreksatu i cytarabiny penetrują do ośrodkowego układu nerwowego (OUN) - jest rekomendowany u chorych ze wznową w OUN. W przypadku stosowania schematu HyperCVAD/MA (8 cykli podawanych naprzemiennie) odsetek uzyskiwanych $\mathrm{CR}$ wynosi $44-47 \%$ [6, 7]. Rekomenduje się jednoczesną dokanałową profilaktykę OUN.

W leczeniu pacjentów $z$ nawrotową/oporną $(\mathrm{R} / \mathrm{R}$, relapsed/refractory) ALL stosuje się wiele schematów polichemioterapii [6-13]. Porównując wyniki leczenia zgodnie $z$ poszczególnymi schematami, należy zachować ostrożność ze względu na zróżnicowany wiek chorych kwalifikowanych do badań, różny czas trwania CR1 czy różną terapię stosowaną w leczeniu pierwszego i kolejnych nawrotów. W badaniu II fazy prowadzonym przez Polską Grupę ds. Leczenia Białaczek u Dorosłych (PALG, Polish Adult Leukemia Group) wykazano, że zastosowanie chemioterapii według schematu 
FLAM (fludarabina, cytarabina, mitoksantron) u pacjentów $z \mathrm{R} / \mathrm{R}$ ALL umożliwia uzyskanie $\mathrm{CR}$ u 50\% chorych, przy czym odsetek CR był istotnie większy u pacjentów, u których FLAM stosowano jako drugą linię leczenia w porównaniu $z$ chorymi po licznych liniach chemioterapii $(66 \% v$. 13\%; $\mathrm{p}=0,02)$. Wczesna śmiertelność była statystycznie częstsza wśród chorych w wieku 40 lub więcej lat niż wśród młodszych pacjentów (33\% v. 8\%; $\mathrm{p}=0,03)$ [13].

W przypadku stosowania schematu FLAG (fludarabina, cytarabina, czynnik wzrostu kolonii granulocytów) lub jego połączeniu $z$ idarubicyną (FLAG-Ida) u chorych na R/R ALL odsetek uzyskiwanych CR wynosił 39-83\% [9, 14]. Inne schematy chemioterapii, oparte na kombinacjach antracyklin, małych dawek cytarabiny, asparaginazy i metotreksatu, pozwalają uzyskać CR u 58-74\% chorych $[15,16]$.

Kolejnym lekiem stosowanym w tej grupie chorych jest analog purynowy - klofarabina. Lek ten zarejestrowano do leczenia dzieci i młodych dorosłych (do 21. rź.) chorych na R/R ALL, po niepowodzeniu co najmniej dwóch wcześniejszych standardowych cykli. Zastosowanie klofarabiny $\mathrm{w}$ monoterapii u dorosłych chorych pozwala na uzyskanie CR jedynie u $17 \%$ pacjentów [10]. Skuteczniejsze jest połączenie klofarabiny $z$ takimi lekami, jak etopozyd, mitoksantron, cytarabina, cyklofosfamid, asparaginaza czy deksametazon, co pozwala uzyskać CR u 36-44\% chorych [11, 17, 18].

Alkaloidy vinca wykazują działanie neurotoksyczne, co ogranicza ich stosowanie w większych dawkach. Liposomalna forma winkrystyny (VSLI, vincristine sulfate liposome injection), w której nanocząsteczka winkrystyny jest zamknięta w sfingomielinowych i cholesterolowych liposomach, to nowy lek stosowany w terapii R/R ALL. Umieszczenie winkrystyny w liposamach wydłuża ekspozycję aktywnego leku w krwioobiegu i umożliwia stosowanie większych dawek bez zwiększenia jej toksyczności [19, 20]. Amerykańska Agencja ds. Żywności i leków (FDA, Food and Drug Administration) zarejestrowała liposomalną winkrystynę do leczenia drugiego lub kolejnego nawrotu ALL, a odpowiedź na leczenie, w tym CR, całkowitą remisję $z$ niepełną regeneracją hematopoezy CRi (complete remision with incomplete blood count recovery) i częściową remisję ( $\mathrm{PR}$, partial remission) stwierdzono u $32 \%$ chorych, u których lek stosowano w monoterapii w dawce $2,25 \mathrm{mg} / \mathrm{m}^{2}$ co tydzień do czasu uzyskania odpowiedzi na leczenie, progresji choroby, wystąpienia toksyczności lub decyzji o zmianie terapii, w tym kwalifikacji do
allo-HSCT. Mediana podanych dawek VSLI wynosiła 4 (zakres 1-18) [19].

Nelarabina jest analogiem nukleozydowym zaaprobowanym do leczenia chorych na T-komórkową ALL (T-ALL) po nieskutecznych co najmniej dwóch wcześniejszych schematach chemioterapii. U dzieci i młodych dorosłych $z$ T-ALL zastosowanie nelarabiny w monoterapii pozwoliło uzyskać odpowiedzi CR i PR u 55\% chorych w pierwszej wznowie choroby, a w przypadku drugiego i kolejnego nawrotu u 27\% pacjentów [21]. $Z$ kolei u dorosłych chorych na T-ALL, przy medianie wcześniejszych linii chemioterapii równej dwa, uzyskano 31\% CR i 10\% PR [22].

\section{Przeciwciała monoklonalne w leczeniu ALL}

B-komórkowa ALL (B-ALL) cechuje się ekspresją antygenów CD19, CD79 (antygen cytoplazmatyczny), CD22 (antygen błonowy i cytoplazmatyczny), CD10, CD24, PAX5 i TdT. Antygeny CD34, CD20 i CD52 nie występują we wszystkich podtypach ALL. Według EGIL (European Group for the Immunological Classification of Leukemias) wyróżnia się podtypy immunologiczne, takie jak pro-B (CD10-), common (CD10+, cyIg-) oraz preB (cyIg +, sIg-). Poszczególne antygeny komórek białaczkowych mogą być celem dla immunoterapii.

Rytuksymab, przeciwciało monoklonalne anty-CD20, powszechnie stosowane w leczeniu B-komórkowych chłoniaków nie-Hodgkina (NHL, non-Hodgkin lymphoma), jest obecnie częścią terapii skojarzonej $\mathrm{w}$ wielu protokołach leczenia pierwszej linii u chorych na B-ALL. Dowiedziono, że dodanie rytuksymabu do polichemioterapii według schematu HyperCVAD u chorych na chłoniaka/białaczkę Burkitta pozwoliło uzyskać CR u 86\% leczonych [23]. U chorych na pre-B-ALL dodanie rytuksymabu poprawia odsetek CR z 35\% do 50\% [24]. W większości protokołów stosowanie tego leku jest ograniczone do grupy chorych, u których blasty białaczkowe wykazują ekspresję antygenu CD20 powyżej $20 \%$.

Ofatumumab jest przeciwciałem anty-CD20 typu II, które w skojarzeniu $z$ chemioterapią w badaniach klinicznych II fazy wykazuje się wysoką skutecznością $\mathrm{w}$ terapii pierwszej linii u chorych na ALL, a odsetek CR z ujemną MRD (MRD-) sięga 96\% [25]. Obinutuzumab jest humanizowanym przeciwciałem anty-CD20 typu II, w którym fragment Fc IgG1 zmodyfikowano metodą glikoinżynierii i które, podobnie jak rytuksymab i ofatumumab, zapewne znajdzie zastosowanie w terapii chorych na ALL. 


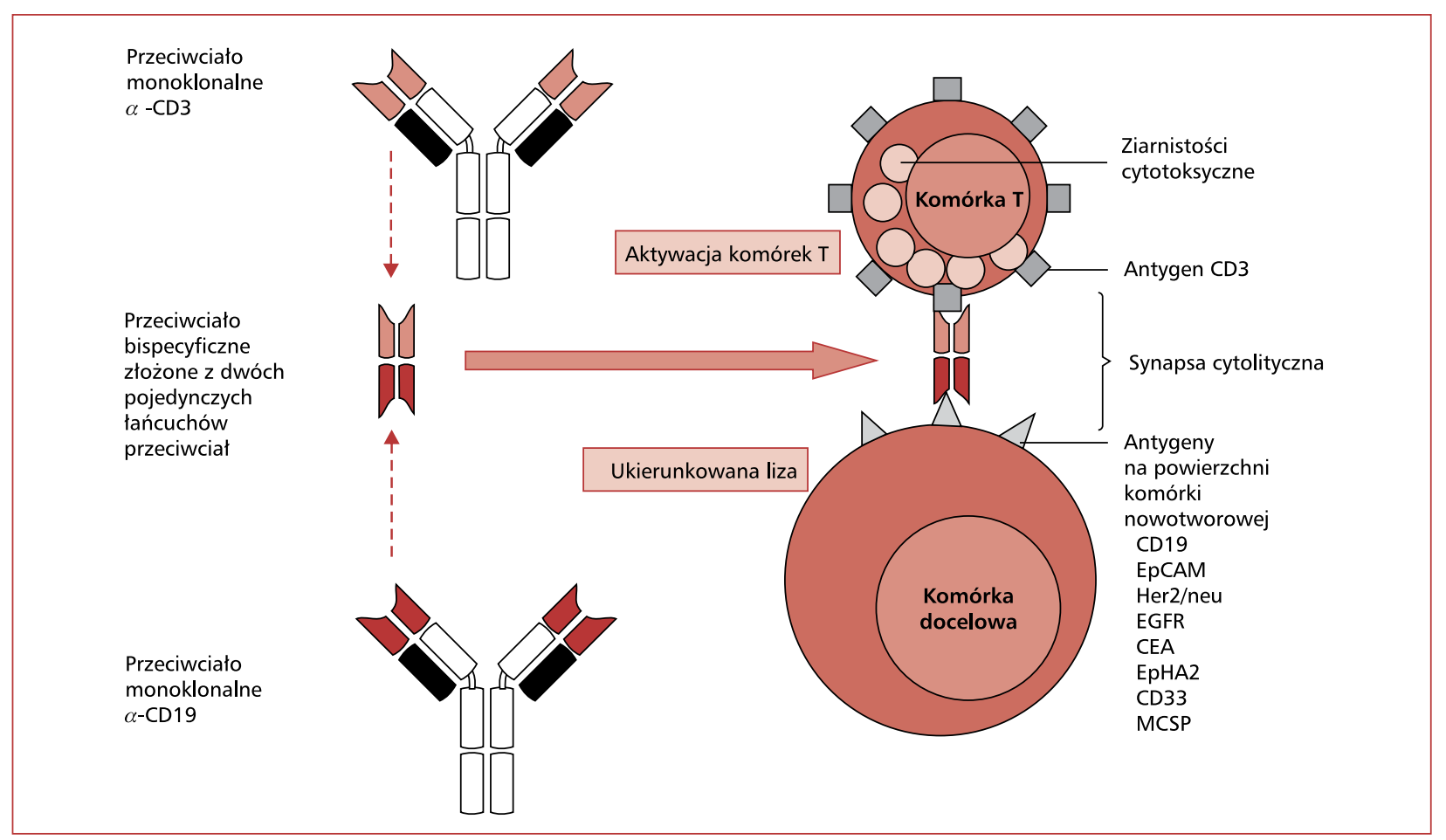

Rycina 1. Mechanizm działania blinatumomabu (opracowano na podstawie [31])

Ekspresję antygenu CD22 stwierdza się na powierzchni komórek białaczkowych u ponad $90 \%$ chorych na ALL. Epratuzumab i inotuzumab ozogamycyny są przeciwciałami skierowanymi przeciwko antygenowi CD22. Skuteczność epratuzumabu w skojarzeniu $z$ klofarabiną i cytarabiną obserwowano w badaniu II fazy u 31 chorych na ALL w pierwszej i kolejnych wznowach choroby. U 16 (52\%) chorych stwierdzono odpowiedź na leczenie, przy czym 10 chorych uzyskało CR, a 6 chorych CRi, zaś mediana OS wynosiła 5 miesięcy [26, 27]. Inotuzumab ozogamycyny jest przeciwciałem monoklonalnym anty-CD22 sprzężonym $z$ kalicheamycyną. Kalicheamycyna ma zdolność do rozcinania podwójnej nici DNA i wyjątkowo silne właściwości cytotoksyczne. W badaniu klinicznym III fazy, służącym porównaniu skuteczności inotuzumabu ozogamycyny ze standardową chemioterapią, odsetek chorych uzyskujących CR był istotnie wyższy w grupie otrzymującej przeciwciało monoklonalne (80,7\% v. 29,4\%; p < 0,001). Wśród chorych, którzy uzyskali CR, odsetek pacjentów z MRD(-) wynosił $78,4 \% \mathrm{w}$ porównaniu $\mathrm{z} 28,1 \% \mathrm{w}$ grupie poddanej standardowej chemioterapii [28].

\section{Blinatumomab}

Budowa cząsteczki i mechanizm działania Blinatumomab (BLINCYTO ${ }^{\circledR}$, Amgen) to pierwsze w swojej klasie bispecyficzne $\left(\mathrm{BiTE}^{\circledR}\right.$, anty-CD19 i anty-CD3) przeciwciało angażujące cytotoksyczne limfocyty $\mathrm{T}(\mathrm{CD} 3+)$ do bezpośredniego niszczenia białaczkowych limfocytów B z ekspresją antygenu CD19. Blinatumomab działa jako „most” aktywujący endogenne limfocyty T, łącząc cząsteczkę CD3 w kompleksie receptora limfocytu T (TCR, T-cell receptor) z cząsteczką CD19 na powierzchni zarówno nowotworowych, jak i prawidłowych limfocytów B [29, 30] (ryc. 1 [31]). Ekspresja antygenu CD19 pojawia się we wczesnych stadiach rozwojowych limfocytów B, dlatego jest atrakcyjnym celem dla immunoterapii.

Blinatumomab jest wytwarzany w komórkach jajnika chomika chińskiego metodą rekombinacji DNA. Dzięki zastosowaniu metody klonowania uzyskano rekombinowane jednołańcuchowe fragmenty Fv o wysokim powinowactwie. Doprowadziło to do powstania biwelentnych, bispecyficznych fragmentów przeciwciała, tak zwanych diprzeciwcial. 
W przypadku blinatumomabu sekwencja DNA pojedynczego fragmentu łańcucha ciężkiego sc Fv (VHA) CD19 jest połączona $z$ sekwencją DNA pojedynczego fragmentu łańcucha lekkiego CD3 sc Fv (VLB) krótką sekwencją łącznikową $z$ wytworzeniem pojedynczego peptydu VHA-VLB. Analogicznie sekwencja DNA pojedynczego łańcucha lekkiego CD19 sc Fv (VLA) jest połączona krótką sekwencją łącznikową z pojedynczym fragmentem łańcucha ciężkiego scFv CD3 z wytworzeniem drugiego peptydu VHB-VLA. Dwa łańcuchy polipeptydowe VHA-VLB i VHB-VLA ulegają niekowalencyjnej heterodimeryzacji $z$ wytworzeniem diprzeciwciała zawierającego bispecyficzne miejsca wiążące antygeny CD19 i CD3. Blinatumomab uczestniczy w tworzeniu synapsy cytolitycznej między limfocytem $\mathrm{T}$ a komórką nowotworową, w której są uwalniane enzymy proteolityczne niszczące zarówno proliferujące komórki docelowe, jak i komórki pozostające w stanie spoczynku [29]. Podanie blinatumomabu wiąże się $z$ przemijającym wzrostem ekspresji komórkowych molekuł adhezyjnych, co powoduje poliklonalną aktywację limfocytów T i uwalnianie $z$ nich cytokin, takich jak: interleukina 2 (IL-2), IL-6, IL-10, interferon $\gamma$ (IFN $\gamma$ ), czynnik martwicy nowotworów $\alpha$ (TNF $\alpha$, tumor necrosis factor $\alpha$ ). Skutkiem jest spadek liczby komórek B CD19+ w ciągu 2 dni oraz przejściowy spadek liczby limfocytów T $\mathrm{CD} 3+\mathrm{z}$ nadirem $\mathrm{w}$ 1. dobie, a następnie $z$ ponownym wzrostem w ciągu kilku dni i podwojeniem ich liczby, już jako komórek pamięci, w 2.-3. tygodniu leczenia. Towarzyszą temu objawy zespolu uwalniania cytokin (CRS, cytokine release syndrome) $\mathrm{w}$ postaci gorączki, bólu głowy, nudności i obniżenia ciśnienia tętniczego, a także objawy zespołu wykrzepiania wewnątrznaczyniowego (DIC, disseminated intravscular coagulation) i zespołu hemofagocytowego. Objawy te zależą od dynamiki choroby podstawowej oraz początkowej dawki leku [29].

\section{Badania I fazy}

\section{z zastosowaniem blinatumomabu}

Pierwsze doświadczenia kliniczne $z$ zastosowaniem blinatumomabu w krótkim wlewie dożylnym i eskalacją dawki uzyskano w trzech badaniach I fazy u 21 pacjentów $z$ nawrotowymi lub opornymi NHL (badania MT103 I/01-2001 i MT103/I/01-2002) oraz u 1 chorego na przewlekłą białaczkę limfocytową (CLL, chronic lymphocytic leukemia) $\mathrm{w}$ badaniu MT103I/01-2003. Blinatumomab w dawkach 0,75$-13 \mu \mathrm{g} / \mathrm{m}^{2}$ podawano raz, dwa lub trzy razy w tygodniu w krótkim 2- lub 4-godzinnym wlewie dożylnym. Najczęściej występujące objawy niepożądane
(AE, adverse events), w postaci gorączki, dreszczy czy osłabienia, były umiarkowanie nasilone i w pełni odwracalne, podobnie jak zmiany w morfologii krwi i koagulogramie. Nie stwierdzono jednak odpowiedzi klinicznej na leczenie ani aktywności biologicznej leku w postaci trwałej redukcji liczby krążących limfocytów B CD19+. U 6 pacjentów obserwowano powikłania neurologiczne pod postacią afazji, ataksji, zaburzeń orientacji i drgawek, co było powodem przerwania ich udziału w badaniach [32].

Na podstawie uzyskanych wyników i biorąc także pod uwagę krótki okres półtrwania leku (ok. $2 \mathrm{~h}$ ), zaprojektowano kolejne badanie I fazy MT103-104 [33]. Do badania włączono pacjentów $z$ chłoniakiem grudkowym (FL, folicular lymphoma), chłoniakiem z komórek płaszcza (MCL, mantle cell lymphoma) i chłoniakiem rozlanym $z$ dużych komórek B (DLBCL, diffuse large $B$-cell lymphoma). Blinatumomab podawano w ciągłym wlewie dożylnym trwającym 4 lub 8 tygodni. Ocena farmakokinetyczna potwierdziła, że taki ciągły wlew pozwala uzyskać stałe, liniowe i dające się przewidzieć stężenie leku w surowicy $\mathrm{w}$ trakcie całego okresu leczenia. Blinatumomab podawano w dawkach $0,5-90 \mu \mathrm{g} / \mathrm{m}^{2} /$ dobę. W pierwszych dniach leczenia obniżenie liczby limfocytów B CD19+ obserwowano przy dawkach $5 \mu \mathrm{g} / \mathrm{m}^{2} /$ dobę i większych, jednak odpowiedź kliniczną na leczenie blinatumomabem u chorych na NHL stwierdzano przy zastosowaniu dawki $15 \mu \mathrm{g} / \mathrm{m}^{2} /$ dobę. Podwojenie dawki $15 \mu \mathrm{g} / \mathrm{m}^{2} /$ dobę nie zwiększyło odsetka odpowiedzi, jednak kolejne jej zwiększenie do $60 \mu \mathrm{g} / \mathrm{m}^{2} /$ dobę pozwolito na dalszą poprawę odpowiedzi na leczenie, tj. CR u 83\% chorych na FL i 71\% chorych na MCL. Dawkę blinatumomabu zwiększano stopniowo, tj. dawkę początkową $5 \mu \mathrm{g} / \mathrm{m}^{2} /$ dobę stosowano w 1. tygodniu leczenia, następnie $15 \mu \mathrm{g} /$ $/ \mathrm{m}^{2} /$ dobę w 2 . tygodniu, aż do dawki $60 \mu \mathrm{g} / \mathrm{m}^{2} /$ dobę od 3. tygodnia leczenia. Pozwoliło to obniżyć ryzyko powikłań neurologicznych związanych $z$ indukowaniem zmian zapalnych w śródbłonku naczyń OUN przez aktywowane limfocyty T CD3+. Powikłania neurologiczne częściej obserwowano u pacjentów z niską wyjściową pulą limfocytów B CD19+ krążących we krwi, które w pierwszej kolejności są celem terapeutycznym dla limfocytów T CD3+, do których przyłączył się blinatumomab [33]. Wyniki powyższych prac posłużyły do zaplanowania badań klinicznych $\mathrm{u}$ chorych na ALL $z$ dodatnią MRD $(\mathrm{MRD}+)$ oraz $\mathrm{u}$ dzieci i dorosłych chorych na R/R ALL.

\section{Blinatumomab w leczeniu}

chorych na ALL z MRD(+)

Pierwsze badanie pilotażowe II fazy z zastosowaniem blinatumomabu dotyczyło chorych 
na ALL $z$ MRD(+) po leczeniu indukującym lub konsolidującym [34, 35]. Obecność MRD na tych etapach leczenia stanowi najważniejszy, niekorzystny czynnik prognostyczny, będący zapowiedzią pełnoobjawowej wznowy choroby występującej w ciągu kilku tygodni lub miesięcy. Chorzy na ALL w CR i z MRD(+) są zwykle w dobrym stanie ogólnym i nie mają objawów charakterystycznych dla pełnoobjawowej wznowy ALL, dlatego interwencja terapeutyczna na tym etapie choroby wydaje się szczególnie uzasadniona. Uzyskanie negatywnego statusu MRD przed allo-HSCT istotnie wpływa na poprawę odległych wyników leczenia. $\mathrm{W}$ badaniu II fazy u 21 chorych na ALL $z$ MRD(+) po leczeniu indukującym lub konsolidującym według protokołu GMALL (German Multicenter Adult ALL Study Group) stosowano dożylny wlew blinatumomabu w dawce $15 \mu \mathrm{g} / \mathrm{m}^{2} /$ dobę w 4 -tygodniowej ciągłej infuzji, po której następowały 2 tygodnie przerwy. Marker molekularny do oceny MRD dobierano indywidulanie dla każdego pacjenta zależnie od podtypu ALL i była nim albo indywidualna rearanżacja genów $I g / T C R$ oceniana metodą reakcji łańcuchowej polimerazy (PCR, polimerase chain reaction), albo specyficzna aberracja (gen fuzyjny $B C R / A B L 1$ lub translokacja $M L L-A F 4$ ) oceniana ilościową metodą PCR w czasie rzeczywistym (RQ-PCR, real-time quantitative PCR). Mediana wieku chorych wynosiła 47 lat. Ocenę skuteczności leczenia przeprowadzono u 20 chorych; 1 pacjenta wyłączono $z$ badania $z$ powodu AE 3 . stopnia według Światowej Organizacji Zdrowia (WHO, World Health Organization). Spośród 20 chorych 16 (80\%) uzyskało negatywizację MRD po zakończeniu 1. cyklu leczenia blinatumomabem. Przy medianie obserwacji wynoszącej 405 dni prawdopodobieństwo przeżycia wolnego od nawrotu choroby (RFS, relapse-free survival) osiagnęło 78\% chorych. U 8 chorych przeprowadzono procedurę allo-HSCT i u żadnego $\mathrm{z}$ nich nie obserwowano nawrotu ALL [34]. W aktualizacji wyników tego badania opublikowanej w 2012 roku w „Blood” stwierdzono, że przy medianie obserwacji równej 33 miesiącom w grupie 20 chorych RFS wyniós1 $61 \%$, a u chorych poddanych allo-HSCT $-65 \%$ [35].

Kolejne badanie potwierdzające wcześniej uzyskane wyniki przeprowadzono w grupie 116 chorych na ALL $z \operatorname{MRD}(+)$, u których blinatumomab podawano w dawce $15 \mu \mathrm{g} / \mathrm{m}^{2} /$ dobę w 4 -tygodniowej ciągłej infuzji, po której następowały 2 tygodnie przerwy. Maksymalnie stosowano 4 cykle leczenia lub co najmniej 1 cykl, jeśli następnie planowano procedurę allo-HSCT. Mediana wieku chorych wynosiła 45 lat (zakres 18-76 lat). Ujemną MRD po 1 . cyklu leczenia uzyskało $78 \%$ chorych, a $80 \%$ chorych - po zastosowaniu co najmniej dwóch cykli terapii blinatumomabem [36].

\section{Blinatumomab w leczeniu chorych na nawrotowa/oporną ALL}

W 2014 roku opublikowano wyniki wieloośrodkowego badania II fazy $z$ zastosowaniem blinatumomabu u 36 chorych na R/R ALL [37]. Do badania kwalifikowano pacjentów $z$ pierwotnie oporną ALL, $z$ nawrotem po leczeniu indukującym i konsolidującym i z nawrotem po allo-HSCT. Kryteria włączenia do badania obejmowały liczbę limfoblastów w szpiku kostnym powyżej 5\%, stan ogólny według ECOG (Eastern Cooperative Oncology Group) 0-2 oraz przewidywany czas przeżycia co najmniej 12 tygodni. Kryteria wyłączenia $z$ badania obejmowały między innymi rozpoznanie ALL Ph-dodatniej, aktywne zajęcie OUN przez proces białaczkowy, istotne klinicznie zaburzenia OUN $\mathrm{w}$ wywiadzie, aktywną chorobę przeszczep przeciw gospodarzowi (GvHD, graft versus host disease) i/lub leczenie immunosupresyjne $z$ powodu GvHD w ciągu 1 tygodnia przed rozpoczęciem leczenia blinatumomabem, aktywną infekcję, immunoterapię $\mathrm{w}$ ciągu ostatnich 4 tygodni oraz chemioterapię podaną $\mathrm{w}$ ciągu ostatnich 2 tygodni przed rozpoczęciem leczenia blinatumomabem. Mediana wieku chorych wynosiła 32 lata (zakres 18-77 lat). Do nawrotu ALL po wcześniejszym allo-HSCT doszło u 15 pacjentów. W schemacie badania zakładano podanie 2 cykli blinatumomabu w reindukcji. W przypadku uzyskania CR lub CR z częściową odnową hematologiczną ( $\mathrm{CRh}$, complete remission with partial hematologic recovery), wyrażającą się liczbą płytek krwi powyżej $50 \mathrm{G} / 1$, stężeniem hemoglobiny powyżej $7 \mathrm{~g} / \mathrm{dl}$ i liczbą neutrofilów powyżej $0,5 \mathrm{G} / 1$, pacjent otrzymywał 3 kolejne cykle konsolidacyjne lub poddawano go procedurze allo-HSCT. Każdy cykl składał się z 4-tygodniowego ciagłego wlewu blinatumomabu $z$ następczą 2-tygodniową przerwą. Lek podawano w warunkach szpitalnych przez 7 dni 1 . cyklu oraz przez pierwsze 2 dni kolejnych cykli. Opakowania $z$ blinatumomabem przygotowanym do ciągłego wlewu zmieniano co 48 godzin w ciągu tygodnia i co 72 godziny w weekendy. Początkowo pacjenci byli podzieleni na 3 kohorty. W pierwszej kohorcie (1) chorzy otrzymywali lek w dawce $15 \mu \mathrm{g} / \mathrm{m}^{2} /$ dobę w ciągu całego cyklu (7 pacjentów), w drugiej grupie (2a) otrzymywali blinatumomab w dawce początkowej $5 \mu \mathrm{g} / \mathrm{m}^{2} /$ dobę, a następnie w dawce zwiększonej do $15 \mu \mathrm{g} / \mathrm{m}^{2} /$ dobę (5 pacjentów). W trzeciej kohorcie (2b) stosowano stopniowe zwiększanie dawki 
od 5 przez 15 do $30 \mu \mathrm{g} / \mathrm{m}^{2} /$ dobę (6 pacjentów). Najwięcej AE i ciężkich objawów niepożądanych (SAE, serious adverse event) obserwowano w kohorcie 1. , tj. $\mathrm{u}$ pacjenta wystąpiły zaburzenia neurologiczne i psychiczne 3. stopnia według WHO, u drugiego objawy CRS w 4. stopniu według WHO. Najmniej $\mathrm{AE}$ i najlepszy profil bezpieczeństwa obserwowano w kohorcie 2a, dlatego kolejnych 18 pacjentów leczono według schematu dla tej kohorty. Wszyscy pacjenci otrzymywali profilaktyczną chemioterapię dokanałową (15 mg metotreksatu, $40 \mathrm{mg}$ cytarabiny i $4 \mathrm{mg}$ deksametazonu) w okresie skriningu do badania oraz w ostatnim dniu każdego cyklu. Jako premedykację stosowano $16 \mathrm{mg}$ deksametazonu godzinę przed rozpoczęciem wlewu blinatumomabu w każdym cyklu. Odpowiedź na leczenie oceniano $\mathrm{w}$ centralnym laboratorium na podstawie biopsji aspiracyjnej lub trepanobiopsji szpiku. Minimalną chorobę resztkową oceniano metodą PCR z odwrotną transkryptazą (RT-PCR, reverse transcriptase $P C R$ ) na podstawie indywidulanej klonalnej rearanżacji genów kodujących łańcuchy Ig lub/i TCR. U 25 (69\%) chorych stwierdzono CR lub CRh. Największy (100\%) odsetek uzyskiwanych odpowiedzi obserwowano u pacjentów $z$ pierwszym nawrotem ALL, zarówno wczesnym, jak i późnym, a najmniejszy $(53 \%, 8 / 15) \mathrm{u}$ chorych $z$ nawrotem po allo-HSCT. U 88\% chorych spośród 15 pacjentów, którzy uzyskali CR lub CRh, stwierdzono MRD(-), przy czym $72 \%$ pacjentów uzyskało status MRD(-) już po 1. cyklu blinatumomabu. Mediana RFS wynosiła 7,6 miesiąca i nie stwierdzono różnic między grupą pacjentów z CR i CRh. Mediana OS dla całej grupy chorych wynosiła 9,8 miesiąca, a dla pacjentów, którzy osiągnęli CR $-13,2$ miesiąca, dla tych z $\mathrm{CRh}-8,3$ miesiąca. Krótszą, ale bez znamienności statystycznej, medianę OS obserwowano $u$ chorych $z$ nawrotem po wcześniejszym allo-HSCT $\mathrm{w}$ porównaniu $\mathrm{z}$ pacjentami, u których wystąpił nawrót po chemioterapii $(8,8$ miesiąca $v .14,1$ miesiąca; $\mathrm{p}=0,2)$. U $13(52 \%)$ chorych, którzy uzyskali CR lub CRh po leczeniu blinatumomabem, przeprowadzono allo-HSCT. W tej grupie było 3 pacjentów, dla których była to kolejna procedura allo-HSCT. Spośród 13 chorych 6 (46\%) zmarło $z$ powodu powikłań związanych $z$ allo-HSCT, u $2(15 \%)$ chorych stwierdzono nawrót choroby. U 12 (48\%) chorych w CR lub CRh po leczeniu blinatumomabem nie przeprowadzono allo-HSCT. Spośród tych chorych u 8 (67\%) stwierdzono nawrót choroby $-\mathrm{u}$ połowy $\mathrm{w}$ trakcie kolejnych cykli leczenia blinatumomabem, u połowy po jego zakończeniu. Łącznie wznowę ALL obserwowano u $10(40 \%, 10 / 25)$ chorych — w 3 przypadkach bez ekspresji CD19 na komórkach białaczkowych (1 wznowa o lokalizacji pozaszpikowej), u 4 chorych stwierdzono ekspresję CD19 na komórkach ALL (2 wznowy o lokalizacji pozaszpikowej), u 1 pacjenta nie był znany status CD19. Nie obserwowano wznowy w ALL w OUN.

Najczęściej raportowanymi AE w trakcie leczenia blinatumomabem były: gorączka $(81 \%)$, osłabienie $(50 \%)$, ból głowy $(47 \%)$, dreszcze (36\%) i leukopenia (19\%). Większość z nich miała charakter przejściowy i występowała jedynie w pierwszych dniach terapii. Najczęściej występującymi AE w co najmniej 3. stopniu według WHO były leukopenia i małopłytkowość. U $67 \%$ pacjentów odnotowano SAE i były to głównie infekcje (33\%) oraz zaburzenia neurologiczne i psychiczne (22\%). Z grupy 36 pacjentów biorących udział w badaniu zmarło 22 (61\%). Jeśli przyczyną zgonu $\mathrm{w}$ tracie leczenia blinatumomabem były powikłania infekcyjne, to występowały u pacjentów, którzy nie uzyskali remisji. Śmiertelne powikłania infekcyjne występowały również po zakończeniu leczenia blinatumomabem, $\mathrm{w}$ okresie potransplantacyjnym, a więc bez bezpośredniego związku $z$ lekiem. U 6 (17\%) pacjentów leczonych blinatumomabem obserwowano zaburzenia w OUN wymagające czasowego wstrzymania lub zaprzestania leczenia. W większości były to objawy 3 . stopnia według WHO, takie jak: drżenia, afazja, dezorientacja, drgawki, napad padaczkowy. U 5 chorych objawy te wystąpiły w pierwszym tygodniu leczenia, a $u 1 z$ nich w pierwszych godzinach po zwiększeniu dawki leku. Po ustąpieniu zaburzeń neurologicznych wszyscy pacjenci ponownie otrzymali wlew blinatumomabu. Pacjentów, u których wystąpiły objawy padaczkowe, poddano profilaktyce przeciwdrgawkowej $z$ dobrym efektem. Natomiast u 2 pacjentów $z$ objawami encefalopatii ostatecznie zakończono wlew blinatumomabu $z$ powodu nawrotu zaburzeń neurologicznych i psychicznych. U $2(5,5 \%)$ chorych obserwowano objawy CRS. W 1 przypadku towarzyszyły temu objawy zespołu lizy guza. Obaj pacjenci uzyskali CR, choć jeden $z$ nich nie kontynuowal już leczenia blinatumomabem. Objawy CRS stwierdzano u pacjentów $z$ wyjściową dużą masą komórek nowotworowych (naciek ALL w szpiku 88-90\%) oraz z obecnością nacieków o lokalizacji pozaszpikowej. Dlatego $\mathrm{u}$ takich chorych zalecano stosowanie przedleczenia złożonego $\mathrm{z}$ deksametazonu $\mathrm{w}$ dawce maksymalnie do $10 \mathrm{mg} / \mathrm{m}^{2}$ przez $1-5 \mathrm{dni}$ i/lub cyklofosfamidu w dawce $200 \mathrm{mg} / \mathrm{m}^{2}$ przez maksymalnie 4 dni. U chorych, którzy nie uzyskali CR, nie obserwowano objawów CRS [37]. 
W 2015 roku opublikowano odległe wyniki 36 chorych leczonych blinatumomabem w wyżej wymienionym badaniu II fazy [38]. Mediana RFS w grupie 25 chorych, którzy uzyskali CR/CRh, wynosiła 8,8 miesiąca, a plateau osiągnięto po 18 miesiącach u 6 chorych. Spośród nich u 4 jako konsolidację, po 2 cyklach indukujących blinatumomabem, przeprowadzono allo-HSCT, 2 kolejnych pacjentów otrzymało 3 dodatkowe cykle blinatumomabu bez allo-HSCT. U 3 spośród 25, którzy uzyskali CR lub $\mathrm{CRh}$, ale $\mathrm{z} \mathrm{MRD}(+)$, obserwowano nawrót choroby po, odpowiednio: kilkunastu dniach, 2 miesiącach, 9 miesiącach. Przy medianie obserwacji 32,6 miesiąca mediana OS dla całej grupy chorych wynosiła 13 miesięcy, a plateau osiągnięto po około 33 miesiącach. Całkowite przeżycie trwające co najmniej 30 miesięcy określono jako długotrwałe. Nie obserwowano różnic w zakresie OS między grupą pacjentów, którzy otrzymali blinatumomab jako leczenie wznowy po wcześniejszym allo-HSCT a grupą chorych, u których doszło do wznowy bez wcześniejszego allo-HSCT.

Do dalszej analizy pacjentów podzielono na 3 grupy. W pierwszej, 10-osobowej, byli pacjenci z co najmniej 30-miesięcznym OS i z MRD(-). W drugiej, 15-osobowej, grupie znaleźli się chorzy z OS poniżej 30 miesięcy i również MRD(-). Do trzeciej grupy zaliczono chorych z OS poniżej 30 miesięcy i $\operatorname{MRD}(+)$. Nie wykazano różnic w zakresie liczby wcześniejszych linii leczenia ratunkowego, wcześniejszych allo-HSCT ani zastosowanego przedleczenia (deksametazon i/lub cyklofosfamid). Mediana liczby blastów przed leczeniem była niższa u chorych $z$ OS sięgającym co najmniej 30 miesięcy, ale różnica ta nie była istotna statystycznie. Wśród pacjentów z co najmniej 30-miesięcznym OS i MRD(-) było 7 pacjentów z CR, 2 z CRh oraz 1 chory $z$ hipoplastycznym szpikiem. W tej 10-osobowej grupie u 6 chorych jako konsolidację zastosowano allo-HSCT (w tym u 3 chorych ze wznową po wcześniejszym allo-HSCT) i 5 chorych pozostawało pod obserwacją w momencie publikacji wyników. Wśród nich był 1 pacjent $z \mathrm{MRD}(-)$ i hipoplastycznym szpikiem po indukcji blinatumomabem. Pozostali 4 chorzy z 10-osobowej grupy, u których nie przeprowadzono konsolidacji allo-HSCT, również pozostawali pod obserwacją w momencie publikacji wyników, jednak u 2 z nich stwierdzono wznowy ALL, które nie dotyczyły OUN. U pierwszego pacjenta wznowę ALL stwierdzono 2-krotnie - pierwsza nastąpiła po 12 miesiącach od zakończenia 5 . cyklu blinatumomabu, a limfoblasty wykazywały ekspresję CD19. Chory otrzymał 3 cykle blinatumomabu w obu reindukcjach, uzyskując CR z MRD(-). U drugiego chorego wznowę ALL $z$ limfoblastami bez ekspresji CD19 obserwowano po 3 cyklach blinatumomabu. Chory otrzymał w reindukcji chemioterapię według schematu FLAG-Ida, a następnie przeprowadzono u niego allo-HSCT. Należy podkreślić, że w 10-osobowej grupie pacjentów $z$ długotrwałym OS u 3 chorych wystąpiły zaburzenia neurologiczne lub CRS, które były przyczyną czasowego przerwania leczenia. $\mathrm{W}$ badaniu analizowano również kinetykę zmian w liczbie limfocytów T CD3+ i komórek B $\mathrm{CD} 19+$, oceniając ich medianę w czasie 1 . i 2 . cyklu leczenia indukującego blinatumomabem. Zwiększenie liczby limfocytów T CD3+ obserwowano głównie u chorych $z$ 10-osobowej grupy $z$ co najmniej 30-miesięcznym OS i MRD(-). U pacjentów $z \mathrm{MRD}(-)$, ale $z$ OS poniżej 30 miesięcy wzrost liczby limfocytów T CD3+ stwierdzono tylko w cyklu 1., a u chorych $z \mathrm{MRD}(+)$ w ogóle nie obserwowano tego zjawiska. Wzrostowi subpopulacji limfocytów T CD3+ u pacjentów z długotrwałym przeżyciem towarzyszył również wzrost liczby efektorowych limfocytów $\mathrm{T}$ pamięci pełniących ważną rolę $\mathrm{w}$ indukowanej przez blinatumomab apoptozie białaczkowych komórek B CD19+. W odniesieniu do kinetyki komórek B CD19+ u pacjentów z MRD(-) obserwowano częściową deplecję komórek B w 3. dniu leczenia $(\leq 1 \mathrm{komórki} / \mu \mathrm{l})$ i całkowitą od 8. doby, która utrzymywała się przez całe 1 . i 2 . cykl leczenia blinatumomabem, niezależnie od wartości OS powyżej lub poniżej 30 miesięcy. U chorych z MRD $(+)$ mediana czasu trwania deplecji komórek B CD19+ wynosiła 22 dni, a limfocyty CD19+ obserwowano ponownie przy rozpoczęciu 2 . cyklu, tj. w dniu 43. Autorzy pracy uważają, że o ile deplecja komórek B CD19 + we krwi obwodowej wiąże się z osiągnięciem całkowitej odpowiedzi molekularnej, czyli MRD(-), o tyle zwiększenie liczby limfocytów T CD3+ koreluje z dłuższym OS [38].

W 2015 roku opublikowano wyniki kolejnego, wieloośrodkowego badania II fazy z zastosowaniem blinatumomabu w leczeniu 189 pacjentów $z \mathrm{R} / \mathrm{R}$ ALL $\mathrm{Ph}(-)$ [39]. Do badania zakwalifikowano chorych z 23 ośrodków w Europie i 14 w Stanach Zjednoczonych, u których stwierdzono pierwotną oporność na leczenie indukujące lub wczesny pierwszy nawrót ( $\mathrm{w}$ ciągu 12 miesięcy od uzyskania CR1), nawrót w ciągu 12 miesięcy po allo-HSCT albo brak remisji lub nawrót po pierwszym lub kolejnym leczeniu ratunkowym. Kryteria włączenia do badania obejmowały ponadto liczbę limfoblastów w szpiku kostnym co najmniej $10 \%$ i stan ogólny według ECOG 0-2. Kryteria wyłączenia $z$ badania obejmowały między innymi aktywne zajęcie OUN 
przez ALL, klinicznie istotne zaburzenia OUN, ostrą GvHD, aktywną przewlekłą GvHD (w stopniu 2.-4.), procedurę allo-HSCT w ciągu 3 miesięcy poprzedzających rozpoczęcie leczenia blinatumomabem, chemio-, radioterapię lub systemowe leczenie GvHD w ciągu 2 tygodni przed rozpoczęciem leczenia blinatumomabem oraz immunoterapię lub leczenie w ramach innego badania klinicznego lekiem przeciwnowotworowym w ciagu ostatnich 2 tygodni. Wśród chorych włączonych do badania u 64 (34\%) stwierdzano nawrót ALL po wcześniejszym allo-HSCT, a 96 (51\%) pacjentów otrzymało jedną lub więcej linii leczenia ratunkowego, ale bez allo-HSCT. W celu obniżenia ryzyka wystąpienia CRS u pacjentów z ponad 50-procentowym naciekiem ALL w szpiku kostnym, liczbą blastów powyżej $15 \mathrm{G} / 1$ we krwi obwodowej lub podwyższoną aktywnością dehydrogenazy mleczanowej (LDH, lactate dehydrogenase) obowiązkowo stosowano przedleczenie deksametazonem w dawce $10-24 \mathrm{mg} /$ $/ \mathrm{m}^{2} /$ dobę (maksymalnie do 5 dni). Profilaktykę CRS zastosowano u 97 (51\%) pacjentów zakwalifikowanych do badania. Przedleczenie należało zakończyć 3 dni przed pierwszą dawką blinatumomabu i powtórzyć badanie szpiku kostnego w celu wykazania obecności co najmniej $10 \%$ blastów. Rozpoczęcie ciągłego wlewu blinatumomabu musiało być poprzedzone dodatkową premedykacją steroidową (20 mg deksametazonu). Leczenie rozpoczynano od dawki $9 \mu \mathrm{g}$ /dobę przez pierwsze $7 \mathrm{dni}$, a następnie, po ponownej premedykacji steroidowej, dawkę blinatumomabu zwiększano do $28 \mu \mathrm{g}$ /dobę. Lek podawano, podobnie jak we wcześniejszym badaniu II fazy, w ciągłej infuzji dożylnej przez 4 tygodnie, po których następowała 2 -tygodniowa przerwa. Pacjenci, którzy uzyskali CR lub CRh po 2 cyklach indukujących, mogli otrzymać 3 kolejne cykle blinatumomabu. Na każdym etapie leczenia chory mógł być zakwalifikowany do procedury allo-HSCT zgodnie $z$ decyzją badacza. Wlew blinatumomabu należało przerwać, jeśli wystąpiły zaburzenia neurologiczne 3. stopnia lub inne $\mathrm{AE}$ istotne kliniczne 3. lub 4. stopnia według WHO, ale leczenie mogło być wznowione po ich ustąpieniu. Każde wznowienie leczenia wymagało premedykacji steroidowej. Jeśli przerwa w podawaniu leku wynosiła więcej niz 2 tygodnie $z$ powodu wystąpienia $\mathrm{AE}$ albo $z$ powodu powikłań neurologicznych 4. stopnia według WHO lub po 2-krotnym napadzie padaczkowym, to leczenie blinatumomabem nie mogło być kontynuowane. Pierwszorzędowym punktem końcowym badania był odsetek CR i CRh w ciągu pierwszych 2 cykli leczenia blinatumomaem. Drugorzędowymi punktami końcowymi były: RFS, OS, odsetek pacjentów, u których było możliwe wykonanie procedury allo-HSCT po uzyskaniu CR lub CRh po leczeniu blinatumomabem, śmiertelność w +100 . dobie po allo-HSCT oraz częstość i nasilenie AE. Spośród 189 pacjentów włączonych do badania 81 (43\%) uzyskało CR lub CRh $(33 \%$ CR i $10 \%$ CRh) w ciągu pierwszych 2 cykli leczenia blinatumomabem, w tym większość (79\%) chorych już po 1 . cyklu. Remisje (CR lub $\mathrm{CRh}$ ) częściej obserwowano u chorych, u których naciek szpiku wynosił poniżej 50\% niż u tych $z$ naciekiem szpiku $50 \%$ lub większym (73\% v. 29\%). Łączne odsetki CR i CRh były podobne u chorych ze wznową po wcześniejszym allo-HSCT, jak i bez allo-HSCT (45\% v. 42\%). Przy medianie obserwacji 8,9 miesiąca 37 (45\%) spośród 81 pacjentów, którzy osiągnęli CR lub CRh, pozostawało w remisji, u 37 chorych stwierdzono nawrót ALL, 8 pacjentów zmarło bez udokumentowanej wznowy, w tym 6 po allo-HSCT. U 6 chorych obserwowano wczesny nawrót ALL, tj. w trakcie 1. lub 2. cyklu blinatumomabu. Mediana RFS wynosiła 5,9 miesiąca u pacjentów w CR lub CRh (6,9 miesiąca u chorych w CR i 5 miesięcy u chorych w CRh). Przy medianie obserwacji 9,8 miesiąca mediana OS u wszystkich 189 chorych wynosiła 6,1 miesiąca. U 73 pacjentów, którzy osiągnęli $\mathrm{CR}$ lub $\mathrm{CRh} \mathrm{w}$ czasie leczenia indukującego (pierwsze 2 cykle blinatumomabu), oceniano MRD. U 60 (82\%) chorych stwierdzono $\mathrm{MRD}(-)$, w tym u 59 pacjentów po 1 . cyklu. Mediana RFS wynosiła 6,9 miesiąca u chorych $z \mathrm{MRD}(-)$ w porównaniu $\mathrm{z}$ 2,3 miesiąca u pacjentów $z \operatorname{MRD}(+)$. Mediany OS wynosily odpowiednio 11,5 miesiąca $v$. 6,7 miesiąca. U 99\% chorych $\mathrm{w}$ trakcie całego badania wystąpiły $\mathrm{AE}$ związane $z$ blinatumomabem o różnym stopniu nasilenia. Najczęściej były to gorączka (60\%), ból głowy (34\%), gorączka neutropeniczna (28\%), obrzęki obwodowe (26\%), nudności (24\%), hipokaliemia (24\%), zaparcia (21\%) i niedokrwistość (20\%). Objawy niepożądane 3. stopnia według WHO stanowiły $38 \%$, 4. stopnia - 30\% i najczęściej były to gorączka neutropeniczna, neutropenia i niedokrwistość. U 4 pacjentów wystąpiły objawy DIC. U 3 chorych obserwowano objawy CRS, w tym u 2 pacjentów uzyskano CR lub CRh, a 1 chory zmarł $z$ powodu progresji ALL. U 19 (10\%) chorych konieczne było zmniejszenie dawki blinatumomabu $z$ powodu $\mathrm{AE}$, a u $34(18 \%)$ z tego powodu doszło do przerwania leczenia. Wskutek SAE, głównie wywołanych przez infekcje, zmarło 23 (12\%) pacjentów. U kolejnych 5 chorych przyczyną zgonu była progresja lub nawrót ALL. Infekcje zakończone zgonem obserwowano u 9 pacjentów, którzy zmarli przed pierwszą oceną 
Tabela 1. Charakterystyka 83 chorych, którzy uzyskali CR lub CRh po leczeniu blinatumomabem (źródło [40])

Table 1. Characteristics of 83 patients in CR or CRh after blinatumomab treatment (source [40])

\begin{tabular}{|c|c|c|}
\hline & Allo-HSCT & Bez allo-HSCT \\
\hline Liczba chorych (\%) & $34(41 \%)$ & $49(59 \%)$ \\
\hline Liczba chorych z MRD(-) & $27(79 \%)$ & $34(69 \%)$ \\
\hline Płeć $\mathrm{M} / \mathrm{K}(\%)$ & $19 / 15(56 / 44)$ & $31 / 18(63 / 37)$ \\
\hline $\begin{array}{l}\text { Mediana wieku (zakres) } \\
\text { - } 18-35 \text { lat }(\%) \\
\text { - } 35-55 \text { lat }(\%) \\
\text { - 55-64 lata }(\%) \\
\text { - } \geq 65 \text { lat }(\%)\end{array}$ & $\begin{array}{l}31(18-65) \\
19(56 \%) \\
9(26 \%) \\
4(12 \%) \\
2(6 \%)\end{array}$ & $\begin{array}{l}42(19-75) \\
21(43 \%) \\
12(24 \%) \\
6(12 \%) \\
10(20 \%)\end{array}$ \\
\hline $\begin{array}{l}\text { Liczba nawrotów (\%) } \\
-0 \\
-1 \\
-2 \\
-\geq 3\end{array}$ & $\begin{array}{c}4(12 \%) \\
21(62 \%) \\
8(24 \%) \\
1(3 \%)\end{array}$ & $\begin{array}{c}3(6 \%) \\
30(61 \%) \\
10(20 \%) \\
6(12 \%)\end{array}$ \\
\hline $\begin{array}{l}\text { Liczba wcześniejszych linii leczenia (\%) } \\
-0 \\
-1 \\
-2 \\
-123\end{array}$ & $\begin{array}{c}9(27 \%) \\
17(50 \%) \\
5(15 \%) \\
3(9 \%)\end{array}$ & $\begin{array}{c}10(20 \%) \\
20(41 \%) \\
9(18 \%) \\
10(20 \%)\end{array}$ \\
\hline Liczba procedur allo-HSCT przed leczeniem blinatumomabem (\%) & $7(21 \%)$ & $22(45 \%)$ \\
\hline
\end{tabular}

M - mężczyźni; K - kobiety; MRD (minimal residual disease) - minimalna choroba resztkowa; MRD(-) - ujemna MRD; allo-HSCT (allogeneic hematopoietic stem cell transplantation) - allogeniczne przeszczepienie krwiotwórczych komórek macierzystych

odpowiedzi na leczenie oraz u 18 chorych, którzy nie odpowiedzieli na leczenie blinatumomabem. $\mathrm{U}$ żadnego chorego w CR lub CRh nie odnotowano zgonu w trakcie leczenia blinatumomabem. U 98 (52\%) chorych wystąpiły powikłania neurologiczne, najczęściej $(76 \%, 74 / 98) 1$. lub 2. stopnia według WHO. Większość (87\%) tych objawów obserwowano w trakcie 1 . cyklu i zwykle ustępowały po leczeniu deksametazonem, bez konieczności przerywania wlewu blinatumomabu. Objawy neurologiczne 3. stopnia według WHO wystąpiły u 20 (11\%) pacjentów i u większości (85\%) były odwracalne, jednak 3 osoby zmarly z innych przyczyn po ich wystąpieniu. Objawy neurologiczne 4 . stopnia według WHO wystąpiły jedynie u $4(2 \%)$ chorych i wszystkie miały charakter odwracalny. W badaniu nie obserwowano powikłań neurologicznych, które zakończyłyby się zgonem chorego [39].

Wyniki zastosowania allo-HSCT u pacjentów z R/R ALL w remisji po blinatumomabie

W 2016 roku na konferencji EBMT przedstawiono aktualizację powyższego badania II fazy dotyczącą wyników allo-HSCT, które przeprowadzono u chorych w CR lub CRh po leczeniu blinatumomabem [40]. Charakterystykę chorych przedstawiono w tabeli 1. Ostatecznie, spośród 189 pacjentów z R/R ALL Ph(-), CR lub CRh uzyskało 83 (44\%) chorych, w tym 74 (61\%) osiągnęło MRD(-). Spośród chorych w CR lub CRh u 34 (41\%) pacjentów przeprowadzono procedurę allo-HSCT. Jednocześnie należy podkreślić, że uzyskanie remisji po leczeniu blinatumomabem pozwoliło wykonać allo-HSCT u 27 (50\%) chorych spośród 54, u których wcześniej transplantacja nie była możliwa z powodu oporności na leczenie. Procedurę allo-HSCT wykonywano najczęściej po 2 cyklach blinatumomabu. Mediana czasu od ostatniej dawki leku do rozpoczęcia kondycjonowania wynosiła $23 \mathrm{dni}$, a od rozpoczęcia leczenia blinatumomabem - 103 dni. Częściej (44\%) stosowano kondycjonowanie mieloablacyjne, u $68 \%$ chorych przeprowadzano przeszczepienie od dawcy niespokrewnionego (MUD allo-HSCT, matched unrelated donor allo-HSCT). Przy medianie obserwacji 13,9 miesiąca nie osiągnięto mediany RFS, podobnie przy medianie obserwacji dla OS równej 13,4 miesiąca nie osiągnięto mediany OS. Prawdopodobieństwo 12-miesięcznego RFS osiągnęło 54\%, a 12-miesięcznego OS - 62,1\% chorych. Czterech $(12 \%, 4 / 34)$ chorych zmarło w ciagu pierwszych 100 dni z powodu powikłań związanych $z$ procedurą $-1 \mathrm{z}$ powodu GvHD ( +42 . doba), 3 z powodu sepsy $(+8 .+59 . \mathrm{i}+75$. doba) [40].

Skuteczność blinatumomabu w leczeniu wznowy po allo-HSCT

W 2016 roku na konferencji EBMT przedstawiono również aktualizację powyższego badania 
Tabela 2. Charakterystyka chorych leczonych blinatumomabem z uwzględnieniem wcześniej przeprowadzonej allo-HSCT (źródło [41])

Table 2. Characteristics of patients treated with blinatumomab according to prior allo-HSCT (source [41])

\begin{tabular}{|c|c|c|}
\hline & \multicolumn{2}{|c|}{ Wcześniejsze allo-HSCT } \\
\hline & Tak & Nie \\
\hline Liczba chorych & 64 & 125 \\
\hline Płeć męska (\%) & $43(67 \%)$ & $76(61 \%)$ \\
\hline Mediana wieku (zakres) & $32(19-74)$ & $42(18-79)$ \\
\hline \multicolumn{3}{|l|}{ Grupy wiekowe (\%) } \\
\hline - 18-35 lat & $40(63 \%)$ & $50(40 \%)$ \\
\hline - 35-55 lat & $13(20 \%)$ & $33(26 \%)$ \\
\hline - 55-64 lata & $9(14 \%)$ & $19(15 \%)$ \\
\hline - $\geq 65$ lat & $2(3 \%)$ & $23(18 \%)$ \\
\hline \multicolumn{3}{|l|}{ Rodzaj dawcy do allo-HSCT(\%): } \\
\hline - haploidentyczny & $1(2 \%)$ & - \\
\hline - spokrewniony & $29(45 \%)$ & \\
\hline - niespokrewniony & $31(48 \%)$ & \\
\hline - spokrewniony/niespokrewniony & $2(3 \%)$ & \\
\hline - haploidentyczny/niespokrewniony & $1(2 \%)$ & \\
\hline Kondycjonowanie mieloablacyjne (\%) & $34(59 \%)$ & - \\
\hline Ostre GvHD (po wcześniejszym allo-HSCT) & $19(30 \%)$ & - \\
\hline Mediana czasu od allo-HSCT do nawrotu w miesiącach (zakres) & $6(1-33)$ & - \\
\hline $\begin{array}{l}\text { Mediana czasu od allo-HSCT do pierwszej dawki blinatumomabu w miesiącach (za- } \\
\text { kres) }\end{array}$ & $10(3-40)$ & - \\
\hline \multicolumn{3}{|l|}{ Liczba wcześniejszych linii leczenia ratunkowego: } \\
\hline$\cdot 0$ & $9(14 \%)$ & $29(23 \%)$ \\
\hline - 1 & $22(34 \%)$ & $55(44 \%)$ \\
\hline$\cdot 2$ & $13(20 \%)$ & $29(23 \%)$ \\
\hline$\cdot \geq 3$ & $20(31 \%)$ & $12(10 \%)$ \\
\hline $\begin{array}{l}\text { Liczba pacjentów wcześniej poddanych leczeniu ratunkowemu, po allo-HSCT, a przed } \\
\text { badaniem z zastosowaniem blinatumomabu }\end{array}$ & $38(69 \%)$ & - \\
\hline
\end{tabular}

II fazy dotyczącą skuteczności reindukcji blinatumomabem u chorych ze wznową po wcześniejszym allo-HSCT [41]. Do analizy włączono 64 pacjentów, u których stwierdzono nawrót ALL po wcześniejszym allo-HSCT. Charakterystykę kliniczną chorych zawiera tabela 2 . Po 2 cyklach blinatumomabu $29(45 \%, 29 / 64)$ pacjentów uzyskało CR $(62 \%, 18 / 29)$ lub CRh $(38 \%, 11 / 29)$, w tym $22(76 \%)$ chorych już po 1 . cyklu. U 4 (6\%) pacjentów stwierdzono hipoplastyczny szpik, bez blastów. Spośród 18 chorych, którzy uzyskali CR lub CRh, oceniono także odpowiedź molekularną i u 16 (89\%) stwierdzono MRD(-). U 7 (11\%) pacjentów ponownie przeprowadzono procedurę allo-HSCT. Wczesna śmiertelność związana $z$ procedurą wynosiła $14 \%$. Mediana RFS u 29 chorych z CR/CRh wynosiła 7,4 miesiąca (przy medianie obserwacji 12,4 miesiąca), a mediana OS - 8,5 miesiąca (przy medianie obserwacji 16,6 miesiąca). Objawy niepożądane występowały z podobną częstością i stopniem nasilenia w grupie pacjentów po wcześniejszym allo-HSCT, jak i bez niego (tab. 3). Nie stwierdzono również wpływu leczenia blinatumomabem na częstość występowania czy stopnień nasilenia objawów GvHD [41].

W grudniu 2014 roku blinatumomab (Blincyto ${ }^{\circledR}$, Amgen) uzyskał rejestrację FDA do leczenia chorych na nawrotową lub oporną B-komórkową ALL Ph(-), a w sierpniu 2015 roku lek zarejestrowała w tym wskazaniu EMA (European Medicines Agency). Podstawą rejestracji były wyniki wieloośrodkowego badania II fazy z zastosowaniem 
Tabela 3. Porównanie częstości objawów niepożądanych (AE) u pacjentów w trakcie leczenia blinatumomabem po wcześniejszym allo-HSCT i chorych niepoddanych wcześniej allo-HSCT (źródło [41])

Table 3. Comparing rates of adverse events (AE) during blinatumomab treatment with and without prior allo-HSCT (source [41])

\begin{tabular}{|c|c|c|}
\hline \multirow[t]{2}{*}{ Działania niepożądane } & \multicolumn{2}{|c|}{ Wcześniejsze allo-HSCT } \\
\hline & Tak & Nie \\
\hline Liczba chorych, u których wystąpiły AE (\%) & $64(100 \%)$ & $124(99 \%)$ \\
\hline AE 3. stopnia wg WHO & $20(31 \%)$ & $52(42 \%)$ \\
\hline AE 4. stopnia wg WHO & $28(44 \%)$ & $27(22 \%)$ \\
\hline AE 5. stopnia wg WHO (zakończone zgonem) & $8(13 \%)$ & $20(16 \%)$ \\
\hline Powikłania neurologiczne 3. stopnia wg WHO & $7(11 \%)$ & $14(11 \%)$ \\
\hline CRS 3. stopnia wg WHO & $2(3 \%)$ & $1(1 \%)$ \\
\hline
\end{tabular}

allo-HSCT (allogeneic hematopoietic stem cell transplantation) - przeszczepienie allogenicznych krwiotwórczych komórek macierzystych; WHO (World Health Organization) - Światowa Organizacja Zdrowia; CRS (cytokine release syndrome) - zespół uwalnia cytokin

blinatumomabu w leczeniu 189 pacjentów $z$ R/R ALL $\mathrm{Ph}(-)$.

W 2016 roku na konferencji European Hematology Association (EHA) zaprezentowano wstępne wyniki randomizowanego badania III fazy (TOWER) [42] opublikowane w „New England Journal of Medicine" w 2017 roku [31]. Do badania włączono 405 chorych na R/R ALL, których poddano randomizacji, w stosunku 2:1, do grup leczonej blinatumomabem (271 pacjentów) lub standardową chemioterapią (SOC, standard of care chemotherapy) (134 pacjentów). Standardową chemioterapię wybierał badacz; obejmowała schemat FLAG (fludarabina, cytarabina, czynnik wzrostu kolonii granulocytów) \pm antracyklina, schematy oparte na dużych dawkach cytarabiny, schematy oparte na dużych dawkach metotrekstatu, klofarabinę. Pierwszorzędowym punktem końcowym badania było OS. Charakterystyki chorych $z$ grupy leczonej blinatumumabem lub SOC były podobne: mediana wieku 37 versus 37 lat, płeć żeńska $40 \%$ versus $42 \%$, mediana liczby blastów w szpiku $80 \%$ versus $79 \%$, wcześniejsze leczenie ratunkowe $56 \%$ versus $52 \%$, wcześniejsze allo-HSCT $35 \%$ versus $34 \%$, nawrót po wcześniejszym allo-HSCT $34 \%$ versus $34 \%$. Mediana OS chorych leczonych blinatumomabem była statystycznie dłuższa niż pacjentów otrzymujących $\operatorname{SOC}(7,7$ miesiąca $v .4$ miesiące; $\mathrm{p}=0,01)$. Prawdopodobieństwo 6 -miesięcznego przeżycia wolnego od zdarzeń osiągnęło $31 \%$ chorych leczonych blinatumomabem w porównaniu $z 12 \%$ pacjentów otrzymujących SOC ( $<<0,001)$, a mediany czasu trwania odpowiedzi wynosiły odpowiednio 7,3 oraz 4,6 miesiąca. Częstość uzyskiwanych remisji w ciągu 12 tygodni od rozpoczęcia leczenia była większa w grupie leczonej blinatumomabem niż wśród chorych leczonych SOC w odniesieniu do CR
(34\% v. $16 \%$; $\mathrm{p}<0,001)$ oraz łącznie CR/CRh/CRi (44\% v. 25\%; $\mathrm{p}<0,001)$. U 87\% chorych leczonych blinatumomabem i u $92 \%$ pacjentów leczonych SOC obserwowano AE co najmniej 3. stopnia według WHO, a SAE odnotowano odpowiednio u $62 \%$ i $45 \%$ chorych. Objawy niepożądane zakończone zgonem wystąpiły u $19 \%$ chorych leczonych blinatumomabem i $17 \%$ otrzymujących SOC. Spośród nich u co najmniej $1 \%$ pacjentów obserwowano, odpowiednio w grupach leczenia blinatumomabem i SOC: sepsę (3\% v. 4\%), wstrząs septyczny (2\% v. $0 \%$ ), niewydolność wielonarządową (1\% v. $0 \%)$, niewydolność oddechową (1\% v. 2\%), bakteriemię $(0 \% v .2 \%)$. Według opinii badaczy AE zakończone zgonem mogły się wiązać $z$ terapią u $3 \%$ chorych leczonych blinatumomabem i 7\% leczonych SOC [31]. W badaniu wykazano wysoką skuteczność blinatumomabu oraz akceptowalny poziom toksyczności w porównaniu ze standardową chemioterapią. Komitet Monitorowania Danych (DMC, Data Monitoring Committee) zarekomendował wcześniejsze zakończenia badania, przed planowaną analizą końcową, ze względu na osiągnięcie pierwszorzędowego punktu końcowego, tj. wydłużenie OS $\mathrm{w}$ grupie leczonej blinatumomabem w porównaniu z grupą leczoną SOC [31, 42].

\section{Aspekty praktyczne}

\section{leczenia blinatumomabem}

Blinatumomab należy podawać w ciągłym wlewie dożylnym przez specjalnie zaprogramowaną, zamykaną pompę infuzyjną $z$ alarmem. Ciągły wlew leku trwa 28 dni w każdym cyklu. W indukcji stosuje się 2 cykle ( 28 dni wlewu leku oraz 14 dni przerwy), a następnie po uzyskaniu CR podaje się kolejne 3 cykle konsolidujące i ewentualnie leczenie podtrzymujące (4-tygodniowe cykle 
Tabela 4. Częstość występowania działań niepożądanych (AE) w trakcie leczenia blinatumomabem (źródło [37])

Table 4. Rates of adverse events (AE) during blinatumomab treatment (source [37])

\begin{tabular}{|l|c|}
\hline AE 1. lub 2. stopnia wg WHO & $33(17 \%)$ \\
\hline AE 3. lub 4. stopnia wg WHO & $127(68 \%)$ \\
\hline AE 5. stopnia wg WHO & $28(15 \%)$ \\
\hline \multicolumn{2}{|c|}{ Rodzaj AE $\geq$ 3. stopnia wg WHO występujących } \\
$\mathbf{u} \geq 5 \%$ pacjentów \\
\hline Gorączka neutropeniczna & $53(28 \%)$ \\
\hline Neutropenia & $33(17 \%)$ \\
\hline Niedokrwistość & $38(20 \%)$ \\
\hline Zapalenie płuc & $18(10 \%)$ \\
\hline Małopłytkowość & $21(11 \%)$ \\
\hline Hiperglikemia & $24(13 \%)$ \\
\hline Leukopenia & $19(10 \%)$ \\
\hline Wzrost ALAT & $24(13 \%)$ \\
\hline Hipokaliemia & $45(24 \%)$ \\
\hline Gorączka & $113(60 \%)$ \\
\hline Sepsa & $13(7 \%)$ \\
\hline Hipofosfatemia & $13(7 \%)$ \\
\hline WHO (World Health Organization) - Światowa Organizacja Zdrowia; \\
ALAT (alanine aminotransferase) - aminotransferaza alaninowa
\end{tabular}

z 8-tygodniową przerwą). Wymagane jest podawanie leku przez centralny cewnik naczyniowy lub port naczyniowy (w warunkach ambulatoryjnych). $\mathrm{U}$ pacjenta o masie ciała ponad $45 \mathrm{~kg}$ dawka początkowa leku w 1. tygodniu leczenia indukującego wynosi $9 \mu \mathrm{g} /$ dobę. Ósmego dnia 1. cyklu dawkę należy zwiększyć do $28 \mu \mathrm{g} /$ dobę; utrzymuje się ją w kolejnych cyklach leczenia.

Ze względu na zwiększone ryzyko wystąpienia $\mathrm{AE} \mathrm{w}$ trakcie podawania blinatumomabu, takich jak reakcja nadwrażliwości, CRS czy powikłania neurologiczne związane $z$ rozpoczynaniem leczenia oraz zwiększaniem dawki leku w 8. dobie, konieczna jest hospitalizacja pacjentów od 1 . do 9. doby 1 . cyklu blinatumomabu oraz w 1 . i 2 . dobie 2. cyklu. Rekomenduje się również hospitalizację w przypadku rozpoczynania kolejnych cykli leczenia blinatumomabem oraz wznawiania wlewu leku, jeśli przerwa $\mathrm{w}$ jego podawaniu wynosiła więcej niż 4 godziny.

Obserwacje $z$ badań klinicznych I fazy $z$ blinatumomabem $w$ leczeniu chorych na inne nowotwory układu chłonnego oraz badań II fazy u chorych na ALL pozwoliły ustalić zalecenia dotyczące premedykacji przed rozpoczęciem każdego wlewu leku (tj. na początku każdego cyklu), po przerwie trwającej więcej niż 4 godziny oraz przy zwiększaniu dawki leku. W premedykacji zaleca się deksametazon w jednorazowej dawce $20 \mathrm{mg}$ dożylnie godzinę przed rozpoczęciem wlewu blinatumomabu. W profilaktyce CRS u chorych na ALL $z$ dużą masą guza, definiowaną jako nacieczenie szpiku powyżej 50\% i/lub liczba blastów we krwi obwodowej ponad $15 \mathrm{G} / \mathrm{l}$, i/lub podwyższona aktywność LDH, konieczne jest zastosowanie dodatkowego przedleczenia deksametazonem w dawce 10-24 mg 3-5 dni przed pierwszą dawką blinatumomabu.

Blinatumomab w postaci liofilizowanej jest rozpuszczany w soli fizjologicznej do objętości worka przystosowanego do podłączenia do pompy infuzyjnej, tj. 265-275 ml. Wyjściowa objętość tak przygotowanego leku jest większa od ostatecznie podanej pacjentowi (tj. $240 \mathrm{ml}$ ) ze względu na konieczność wypełnienia 25-35 $\mathrm{ml}$ drenu pompy. Ilość blinatumomabu podanego do tej objętości zależy od dawki, $9 \mu \mathrm{g} /$ dobę (początkowa) lub $28 \mu \mathrm{g} /$ dobę (docelowa), oraz od zaplanowanej częstotliwości zmiany worków infuzyjnych (worki odpowiednio na 24, 48, 72 i 96 h). Każdorazowo do worka infuzyjnego podaje się stabilizer $(5 \mathrm{ml}) \mathrm{w}$ celu przeciwdziałania adhezji leku na wewnętrznej polietylenowej powierzchni worka i cewnika. Należy również zwracać uwagę, aby do drenu prowadzącego $z$ worka do pompy nie zaaspirować powietrza, co może spowodować unieruchomienie pompy infuzyjnej. Przygotowanie i podłączenie wlewu blinatumomabu zajmuje 20$-30 \mathrm{~min}$. Kolejne zmiany worka $\mathrm{z}$ lekiem (po 9. dobie 1. cyklu oraz po 1. dobie kolejnych cykli), zwykle 2-3 razy w tygodniu, może wykonywać w warunkach ambulatoryjnych lub domowych przeszkolony, w obsłudze pompy infuzyjnej, personel pielęgniarski. Blinatumomab w postaci rozpuszczonej, tj. gotowej do infuzji, może być przechowywany w temperaturze pokojowej do 96 godzin (temperatura ciagłego wlewu), a w temperaturze $2-8^{\circ} \mathrm{C}$ nawet do $10 \mathrm{dni}$, na przykład podczas transportu do miejsca zamieszkania pacjenta.

Na podstawie przeprowadzonych badań klinicznych wiadomo, że u wszystkich pacjentów w trakcie leczenia blinatumomabem występowały $\mathrm{AE}$ o różnym stopniu nasilenia według WHO (tab. 4). U połowy chorych doszło do zaburzeń neurologicznych o różnej manifestacji i różnym stopniu nasilenia. Spektrum neurologicznych AE przedstawiono w tabeli 5 [37]. Szczegółowe zalecenia postępowania w przypadku wystąpienie $\mathrm{AE}$ $\mathrm{w}$ trakcie leczenia blinatumomabem są zawarte w charakterystyce produktu leczniczego [30] oraz na stronie internetowej EMA (http:/www.ema. europa.eu.). 
Tabela 5. Częstość objawów neurologicznych występujących u co najmniej $2 \%$ pacjentów leczonych blinatumomabem (źródło [37])

Table 5. Rates of neurological events occurring in at least $2 \%$ of patients treated with blinatumomab (source [37])

\begin{tabular}{|l|c|c|}
\hline Liczba AE (\%) & $\begin{array}{c}\text { Wszystkich } \\
\text { stopni } \\
\text { wg WHO }\end{array}$ & $\begin{array}{c}\geq 3 . \\
\text { stopnia } \\
\text { wg WHO }\end{array}$ \\
\hline Ogółem & $98(52 \%)$ & $24(13 \%)$ \\
\hline Encefalopatia & $10(5 \%)$ & $6(3 \%)$ \\
\hline Stan padaczkowy & $14(7 \%)$ & $3(2 \%)$ \\
\hline Ataksja & $9(5 \%)$ & $3(2 \%)$ \\
\hline Zaburzenia układu nerwowego & $3(2 \%)$ & $3(2 \%)$ \\
\hline Afazja & $7(4 \%)$ & $2(1 \%)$ \\
\hline Zmiany mentalne & $7(4 \%)$ & $2(1 \%)$ \\
\hline Neurotoksyczność & $5(3 \%)$ & $2(1 \%)$ \\
\hline Drżenia & $33(17 \%)$ & $1(<1 \%)$ \\
\hline Zawroty głowy & $26(14 \%)$ & $1(<1 \%)$ \\
\hline Senność & $9(5 \%)$ & $1(<1 \%)$ \\
\hline Zaburzenia mowy (dyzartria) & $6(3 \%)$ & $1(<1 \%)$ \\
\hline Drgawki & $4(2 \%)$ & $1(<1 \%)$ \\
\hline Zaburzenia czucia & $3(2 \%)$ & $1(<1 \%)$ \\
\hline Zaburzenia poznawcze & $3(2 \%)$ & $1(<1 \%)$ \\
\hline
\end{tabular}

AE (adverse events) - działania niepożądane; WHO (World Health Organization) - Światowa Organizacja Zdrowia

\section{Podsumowanie}

Wyniki leczenia dorosłych chorych na R/R ALL $\mathrm{Ph}(-)$ w przypadku zastosowania konwencjonalnej chemioterapii są niezadowalające. Nadzieję daje zastosowanie u tych chorych przeciwciał monoklonalnych lub terapii komórkowych. Przedstawione w pracy wyniki badań klinicznych II i III fazy wskazują na skuteczność blinatumomabu zarówno w odniesieniu do odsetka $\mathrm{CR} / \mathrm{CRh}$, jak i wydłużenia OS w porównaniu ze standardową chemioterapią. Uzyskanie remisji za pomocą blinatumomabu umożliwia u części chorych przeprowadzenie procedury allo-HSCT, która jest jedyną, jak dotąd, metodą terapii dającą szansę na wyleczenie. Wydaje się, że w przyszłości skuteczność i akceptowalny profil toksyczności blinatumomabu sprawią, że lek ten będzie można stosować również w leczeniu pierwszej linii, w monoterapii lub w skojarzeniu $z$ chemioterapią, a pierwsze badania kliniczne w tym wskazaniu juz rozpoczęto. Niezwykle istotnym elementem działania blinatumomabu u chorych na ALL jest również eradykacja MRD, gdyż status MRD to najważniejszy czynnik prognostyczny w ALL. Niezależnie od nowych możliwości tera- peutycznych leczenie chorych na R/R ALL wciąż pozostaje ogromnym wyzwaniem.

\section{Piśmiennictwo}

1. Fielding A.K., Richards S.M., Chopra R. i wsp.; Medical Research Council of the United Kingdom Adult ALL Working Party; Eastern Cooperative Oncology Group. Outcome of 609 adults after relapse of acute lymphoblastic leukemia (ALL); an MRC UKALL12/ /ECOG 2993 study. Blood 2007; 109: 944-950.

2. Oriol A., Vives S., Hernández-Rivas J.M. i wsp.; Programa Español de Tratamiento en Hematologia Group. Outcome after relapse of acute lymphoblastic leukemia in adult patients included in four consecutive risk-adapted trials by the PETHEMA Study Group. Haematologica 2010; 95: 589-596.

3. Terwey T.H., Massenkeil G., Tamm I. i wsp. Allogeneic SCT in refractory or relapsed adult ALL is effective without prior reinduction chemotherapy. Bone Marrow Transplant. 2008; 42: 791-798.

4. Frey N.V., Luger S.M. How I treat adults with relapsed or refractory Philadelphia chromosome-negative acute lymphoblastic leukemia. Blood 2015; 126: 589-596.

5. Cornelissen J.J., Carston M., Kollman C. i wsp. Unrelated marrow transplantation for adult patients with poor-risk acute lymphoblastic leukemia: strong graft-versus-leukemia effect and risk factors determining outcome. Blood 2001; 97: 1572-1577.

6. Faderl S., Thomas D.A., O'Brien S. i wsp. Augmented hyper-CVAD based on dose-intensified vincristine, dexamethasone, and asparaginase in adult acute lymphoblastic leukemia salvage therapy. Clin. Lymphoma Myeloma Leuk. 2011; 11: 54-59.

7. Camera A., Annino L., Chiurazzi F. i wsp. GIMEMA ALL - Rescue 97: a salvage strategy for primary refractory or relapsed adult acute lymphoblastic leukemia. Haematologica 2004; 89: 145-153.

8. Weiss M.A., Aliff T.B., Tallman M.S. i wsp. A single, high dose of idarubicin combined with cytarabine as induction therapy for adult patients with recurrent or refractory acute lymphoblastic leukemia. Cancer 2002; 95: 581-587.

9. Montillo M., Tedeschi A., Centurioni R. i wsp. Treatment of relapsed adult acute lymphoblastic leukemia with fludarabine and cytosine arabinoside followed by granulocyte colony-stimulating factor (FLAG-GCSF). Leuk. Lymphoma 1997; 25: 579-583.

10. Kantarjian H., Gandhi V., Cortes J. i wsp. Phase 2 clinical and pharmacologic study of clofarabine in patients with refractory or relapsed acute leukemia. Blood 2003; 102: 2379-2386.

11. Barba P., Sampol A., Calbacho M. i wsp. Clofarabine-based chemotherapy for relapsed/refractory adult acute lymphoblastic leukemia and lymphoblastic lymphoma. The Spanish experience. Am. J. Hematol. 2012; 87: 631-634.

12. Schiller G., Lee M., Territo M. i wsp. Phase II study of etoposide, ifosfamide, and mitoxantrone for the treatment of resistant adult acute lymphoblastic leukemia. Am. J. Hematol. 1993; 43: 195-199.

13. Giebel S., Krawczyk-Kulis M., Adamczyk-Cioch M. i wsp.; Polish Adult Leukemia Group. Fludarabine, cytarabine, and mitoxantrone (FLAM) for the treatment of relapsed and refractory adult acute lymphoblastic leukemia. A phase study by the Polish Adult Leukemia Group (PALG). Ann. Hematol. 2006; 85: 717-722.

14. Yavuz S., Paydas S., Disel U. i wsp. IDA-FLAG regimen for the therapy of primary refractory and relapse acute leukemia: a single-center experience. Am. J. Ther. 2006; 13: 389-393. 
15. Aldoss I., Pullarkat V., Patel R. i wsp. An effective reinduction regimen for first relapse of adult acute lymphoblastic leukemia. Med. Oncol. 2013; 30: 744.

16. Martino R., Bellido M., Brunet S. i wsp. Intensive salvage chemotherapy for primary refractory or first relapsed adult acute lymphoblastic leukemia: results of a prospective trial. Haematologica 1999; 84: 505-510.

17. Abbi K.K., Rybka W., Ehmann W.C. i wsp. Phase I/II study of clofarabine, etoposide, and mitoxantrone in patients with refractory or relapsed acute leukemia. Clin. Lymphoma Myeloma Leuk. 2015; 15: 41-46.

18. Advani A.S., Gundacker H.M., Sala-Torra O. i wsp. Southwest Oncology Group Study S0530: a phase 2 trial of clofarabine and cytarabine for relapsed or refractory acute lymphocytic leukaemia. Br. J. Haematol. 2010; 151: 430-434.

19. O’Brien S., Schiller G., Lister J. i wsp. High-dose vincristine sulfate liposome injection for advanced, relapsed, and refractory adult Philadelphia chromosome-negative acute lymphoblastic leukemia. J. Clin. Oncol. 2013; 31: 676-683.

20. Silverman J.A., Reynolds L., Deitcher S.R. i wsp. Pharmacokinetics and pharmacodynamics of vincristine sulfate liposome injection (VSLI) in adults with acute lymphoblastic leukemia. J. Clin. Pharmacol. 2013; 53: 1139-1145.

21. Berg S.L., Blaney S.M., Devidas M. i wsp. Phase II study of nelarabine (compound 506U78) in children and young adults with refractory T-cell malignancies: a report from the Children's Oncology Group. J. Clin. Oncol. 2005; 23: 3376-3382.

22. DeAngelo D.J., Yu D., Johnson J.L. i wsp. Nelarabine induces complete remissions in adults with relapsed or refractory T-lineage acute lymphoblastic leukemia or lymphoblastic lymphoma: Cancer and Leukemia Group B study 19801. Blood 2007; 109: 5136-5142.

23. Thomas D.A., Faderl S., O'Brien S i wsp. Chemoimmunotherapy with hyper-CVAD plus rituximab for the treatment of adult Burkitt and Burkitt-type lymphoma or acute lymphoblastic leukemia. Cancer 2006; 106: 1569-1580.

24. Hoelzer D., Gökbuget N. Chemoimmunotherapy in acute lymphoblastic leukemia. Blood Rev. 2012; 26: 25-32.

25. Jabbour E., Kantarajian H., Thomas D. i wsp. Phase II study of the hyper-CVAD regimen in combination with ofatumumab as frontline therapy for adults with Cd-20 positive acute lymphoblastic leukemia. Blood 2013; 122: 2664.

26. Sharkey R.M., Govindan S.V., Cardillo T.M. i wsp. Epratuzumab-SN-38: a new antibody-drug conjugate for the therapy of hematologic malignancies. Mol. Cancer Ther. 2012; 11: 224-34.

27. Advani A.S., McDonough S., Coutre S. i wsp. SWOG S0910: a phase 2 trial of clofarabine/cytarabine/epratuzumab for relapsed/ /refractory acute lymphocytic leukaemia. Br. J. Haematol. 2014; 165: 504-509.

28. Kantarjian H.M., DeAngelo D.J., Stelljes M. i wsp. Inotuzumab ozogamicin versus standard therapy for acute lymphoblastic leukemia. N. Engl. J. Med. 2016; 375: 740-753.

29. Wu J., Fu J., Zhang M. i wsp. Blinatumomab: a bispecific T cell engager (BiTE) antibody against CD19/CD3 for refractory acute lymphoid leukemia. J. Hematol. Oncol. 2015; 8: 104.
30. Charakterystyka Produktu Leczniczego. Aneks 1: Blincyto. Dostępne na: https://ec.europa.eu/health/documents/community-register/.../anx_133349_pl.pdf. Data dostępu: 4.03.2016 r.

31. Kantarjian H., Stein A., Gökbuget N. i wsp. Blinatumomab versus chemotherapy for advanced acute lymphoblastic leukemia. N. Engl. J. Med. 2017; 376: 836-847.

32. Nagorsen D., Kufer P., Baeuerle P.A. i wsp Blinatumomab: a historical perspective. Pharmacol. Ther. 2012; 136: 334-342.

33. Goebeler M., Viardot A., Noppeney R. i wsp. Blinatumomab (CD3/CD19 Bite antybody) results in high response rate in patients with relapsed non-Hodgkin lymphoma (NHL) including MCL and DLBCL. Ann. Oncol. 2011; 22 (supl. 4): 104-105.

34. Topp M.S., Kufer P., Gökbuget N. i wsp. Targeted therapy with the T-cell-engaging antibody blinatumomab of chemotherapy-refractory minimal residual disease in B-lineage acute lymphoblastic leukemia patients results in high response rate and prolonged leukemia-free survival. J. Clin. Oncol. 2011; 29: 2493-2498.

35. Topp M.S., Gökbuget N., Zugmaier G. i wsp. Long-term follow-up of hematologic relapse-free survival in a phase 2 study of blinatumomab in patients with MRD in B-lineage ALL. Blood 2012; 120: 5185-5187.

36. Gökbuget N., Dombret H., Bonifacio M. i wsp. BLAST: a confirmatory, single arm, phase 2 study of Blinatumomab, a bispecific T-cell engager (BiTE) antibody constructor, in patients with minimal residual disease B - precursor acute lymphoblastic leukemia (ALL). Blood 2014; 123: abstrakt 379.

37. Topp M.S., Gökbuget N., Zugmaier G. i wsp. Phase II trial of the anti-cd19 bispecific T cell-engager blinatumomab shows hematologic and molecular remissions in patients with relapsed or refractory B-precursor acute lymphoblastic leukemia. J. Clin. Oncol. 2014; 32: 4134-4140.

38. Zugmaier G., Gökbuget N., Klinger M. i wsp. Long-term survival and T-cell kinetics in relapsed/refractory ALL patients who achieved MRD response after blinatumomab treatment. Blood 2015; 126: 2578-2584.

39. Topp M.S., Gökbuget N., Stein A.S. i wsp. Safety and activity of blinatumomab for adult patients with relapsed or refractory B-precursor acute lymphoblastic leukaemia: a multicentre, single-arm, phase 2 study. Lancet Oncol. 2015; 16: 57-66.

40. Stein A.S., Topp M.S., Gokbuget N. i wsp. Outcomes of hematopoietic stem cell transplantation (HSCT) among adults with relapsed/ /refractory ( $r / r$ ) acute lymphoblastic leukemia (ALL) achieving remission with blinatumomab. EBMT Annual Meeting 2016. Bone Marrow Transplantation Abstract Book 2016, abstrakt O010.

41. Stein A.S. Treatment with anti-CD19 BiTE ${ }^{\circledR}$ blinatumomab in adult patients with relapsed/refractory B-precursor acute lymphoblastic leukemia (r/r ALL) post allogeneic hematopoietic stem cell transplantation. EBMT Annual Meeting 2016, Bone Marrow Transplantation Abstract Book 2016, abstrakt O015.

42. Topp M.S., Stein A.S., Gökbuget N. i wsp. Blinatumomab improved overall survival in patients with relapse or refractory Philadelphia negative B-cell precursor acute lymphoblastic leukemia in a randomized, open-label phase 3 study (TOWER). EHA Annual Meeting 2016. 